\title{
ANALISIS TINGKAT PERMINTAAN DAGING AYAM RAS (BROILER) DI MASA PANDEMI COVID-19 (STUDI KASUS DI PASAR PANARUKAN KECAMATAN PANARUKAN KABUPATEN SITUBONDO)
}

\author{
Puryantoro1*) Nuril Istiqomah ${ }^{2)}$ \\ 1,2Fakultas Pertanian, Universitas Abdurachman Saleh Situbondo, Situbondo \\ Email koresnpondensi : puryantoro@unars.ac.id
}

\begin{abstract}
Abstrak
Permintaan daging ayam ras broiler cenderung meningkat sepanjang tahun, kebutuhan daging pada masa pandemi Covid-19 saat ini sangatlah dibutuhkan untuk memenuhi kebutuhan protein hewani untuk menjaga imunitas tubuh. Tujuan penelitian ini adalah untuk mengetahui secara simultan dan parsial adanya pengaruh pendapatan rumah tangga, jumlah anggota keluarga, umur, tingkat pendidikan, harga daging ayam broiler, jarak lokasi pembelian, harga daging sapi dan harga ikan laut terhadap permintaan daging ayam broiler di masa pandemi covid-19 di pasar tradisional. Populasi penelitian yang digunakan di Pasar Panarukan Kecamatan Panarukan sebanyak 50 responden dan menggunakan teknik accidental sampling (teknik sampling kebetulan). Hasil uji $\mathrm{F}$ menunjukkan bahwa 8 variabel penelitian secara bersama-sama berpengaruh terhadap permintaan daging ayam ras broiler. Sedangkan secara parsial permintaan daging ayam ras broiler hanya dipengaruhi oleh tingkat pendidikan.
\end{abstract}

Kata Kunci: Permintaan; Ayam Ras Broiler; Pandemi Covid 19

\begin{abstract}
Abstrac
The demand for broiler chicken tends to increase throughout the year, the need for meat during the current Covid-19 pandemic is really needed to fulfill the needs of animal protein to maintain body immunity. The purpose of this study was to determine simultaneously and partially the effect of household income, number of family members, age, education level, broiler chicken meat prices, distance to purchase locations, beef prices and sea fish prices on the demand for broiler chicken during the covid pandemic. -19 in traditional markets. The research population used in Panarukan Market, Panarukan District, was 50 respondents and used accidental sampling technique (coincidence sampling technique). The results of the $F$ test indicate that 8 research variables simultaneously affect the demand for broiler chicken meat. Meanwhile, partially the demand for broiler chicken meat is only influenced by the level of education.
\end{abstract}

Keywords: Demand; Broilers; Covid 19 pandemic

\section{PENDAHULUAN}

Secara ekonomi, Indonesia merupakan negara berkembang. Seiring dengan naiknya pendapatan perkapita penduduk, maka kebutuhan akan protein hewani bagi masyarakat juga meningkat. Daging yang paling diminati konsumen adalah daging ayam broiler. Dalam waktu relatif singkat daging ayam broiler menjadi komoditas bisnis peternakan yang strategis dan menggantikan peran ternak lainnya dalam penyediaan daging. Permintaan akan daging ayam ras broiler diperkirakan akan semakin meningkat seiring dengan meningkatnya jumlah penduduk. 
Menurut data Kementrian Pertanian (2013), permintaan ayam ras pedaging nasional dalam setiap tahun mengalami kenaikan. Pada tahun 2013 produksi daging ayam ras sebesar 1,5 juta ton, sedangkan untuk tahun 2014 produksi daging ayam ras sebesar 888,32 ribu ton atau meningkat sebesar 12,14 persen dari tahun 2013. Produksi daging ayam ras tahun 2015 sampai dengan 2020 mengalami peningkatan sekitar 15,16 persen dalam tiap tahunnya. Permintaaan daging ayam ras tahun 2020 sebesar 2.072 .672 ton. Permintaan daging ayam ras yang semakin meningkat di Indonesia membuatpemerintah mengambil kebijakan-kebijakan yang tepat agar permintaan daging ayam ras tetap terpenuhi.

Sejak tahun 2010 Indonesia sudah melaksanakan swasembada daging ayam ras broiler, dimana konsumsi daging nasional didominasi oleh karkas atau daging ayam. Saat ini telah diambil langkah-langkah positif diantaranya pengadaan bibit ternak unggul, manajemen yang handal serta perlu diadakan revitalisasi dan penataan Rumah Potong Ayam (RAP) yang standar, peningkatan mutu dan keamanan pangan serta menjamin kehalalannya (Abubakar, 2009). Bisnis ayam ras pedaging banyak diminati masyarakat dan semakin menggeser ternak ruminansia besar, khususnya ternak sapi potong, dalam memenuhi kebutuhan daging nasional.

Kebutuhan daging di seluruh negara pada masa pandemi Covid-19 saat ini sangatlah dibutuhkan untuk memenuhi kebutuhan protein hewani untuk menjaga imunitas tubuh. Sistem imun atau sistem kekebalan tubuh adalah kondisi seseorang untuk bisa menolak penyakit tertentu terutama melalui mencegah pengembangan mikroorganisme patogen atau menangkal efek produknya. Sistem imun terdiri atas dua yaitu innate immune dan adaptive immune (Indrawati, 2020).

WHO telah merekomendasikan menu gizi seimbang ditengah pandemi Covid-19. Artinya, disetiap menu makanan harus mencakup nutrisi lengkap, baik itu makronutrien seperti karbohidrat, protein, lemak, serta mikronutrien dari vitamin dan mineral. Namun, untuk membuat fondasi daya tahan tubuh yang kuat (building block) kita harus fokus pada asupan protein, (WHO, 2020).

Permintaan daging yang meningkat pada masa pandemi Covid-19 sebagai sumber protein untuk menjaga kekebalan sistem imun. Daging yang sering kali dikonsumsi adalah daging sapi, daging ayam, dan ikan laut. Daging yang saat ini sering dikonsumsi lebih banyak adalah daging ayam ras.

Daging ayam ras pedaging broiler dijual oleh pedagang di berbagai tempat di Kabupaten Situbondo. Pasar tradisional yang tersebar di setiap daerah Kabupaten Situbondo dapat dipastikan terdapat penjual yang menawarkan daging ayam ras pedaging atau yang lebih dikenal masyarakat dengan daging ayam broiler. Ada perbedaan penjual pada setiap pasar tradisional yang terdapat di Kabupaten Situbondo. Di masa pandemi ini konsumen akan lebih memilih tempat yang tidak banyak kerumunan orang seperti di pasar, konsumen akan lebih aman memilih tempat penjual daging ayam ras di pasar kecil contohnya seperti Pasar Panarukan Kabupaten Situbondo.

Berdasarkan hal tersebut maka perlu dikaji lebih dalam tentang analisis permintaan daging ayam ras (broiler) pada masa pandemi Covid-19. Masyarakat diwajibkan untuk lebih banyak mengkonsumsi protein lebih tinggi untuk menjaga kekebalan sistem imun pada tubuh.

Tujuan penelitian ini adalah untuk mengetahui secara simultan dan parsial adanya pengaruh pendapatan rumah tangga, jumlah anggota keluarga, umur, tingkat pendidikan, harga daging ayam broiler, jarak lokasi pembelian, harga daging sapi dan harga ikan laut terhadap permintaan daging ayam broiler di masa pandemi covid-19 di pasar Pasar Panarukan. 


\section{METODE PENELITIAN}

Penelitian ini dilakukan di pasar Panarukan Kecamatan Panarukan Kabupaten Situbondo Provinsi Jawa Timur. Pemilihan lokasi tersebut dilakukan secara sengaja (purposive sampling area). Waktu penelitian dimulai dari awal bulan Januari sampai dengan bulan Juni 2021. Data dikumpulkan dari data primer dan sekunder. Sampel ditentukan dengan menggunakan teknik accidental sampling (teknik sampling kebetulan) dan terkumpul sebanyak 50 responden. Untuk menguji tentang faktor-faktor yang mempengaruhi keputusan konsumen terhadap pembelian ayam ras broiler di pasar Panarukan Kecamatan Panarukan Kabupaten Sitaubondo. Digunakan analisis uji F dan Uji $\mathrm{t}$ serta regresi linear berganda.

$\mathrm{Y}=\mathrm{a}+b_{1} x_{1}+b_{2} x_{2}+b_{3} x_{3}+b_{4} x_{4}+\mathrm{b}_{5} \mathrm{x}_{5}+\mathrm{b}_{6} \mathrm{x}_{6}+\mathrm{b}_{7} \mathrm{x}_{7}+\mathrm{b}_{8} \mathrm{x}_{8}+\mathrm{e}$

Keterangan:

$\begin{array}{lll}\mathrm{Y} & : \text { Jumlah Permintaan Ayam } \\ \mathrm{a} & : & \text { Konstanta } \\ \mathrm{X}_{1} & : & \text { Pendapatan Rumah Tangga } \\ \mathrm{X}_{2} & : & \text { Jumlah Anggota Keluarga } \\ \mathrm{X}_{3} & : & \text { Umur } \\ \mathrm{X}_{4} & : & \text { Tingkat Pendidikan Formal } \\ \mathrm{X}_{5} & : & \text { Harga Daging Ayam Broiler } \\ \mathrm{X}_{6} & : & \text { Jarak Lokasi Pembelian } \\ \mathrm{X}_{7} & : & \text { Harga Daging Sapi } \\ \mathrm{X}_{8} & : & \text { Harga Ikan Laut } \\ \mathrm{e} & : & \text { Variabel Pengganggu }\end{array}$

\section{HASIL DAN PEMBAHASAN}

Analisis Uji Asumsi Klasik

Sebelum dilakukan pengujian terhadap hipotesis, terlebih dahulu dilakukan pengujian terhadap model regresi berganda. Uji asumsi klasik dalam penelitian ini menggunakan uji normalitas, uji multikolinieritas, dan uji heteroskedastisitas. Uji autokorelasi tidak digunakan dalam penelitian ini karena data yang digunakan dalam penelitian ini adalah data cross section bukan data time series.

\section{Uji Normalitas}

Uji normalitas dilakukan dengan tujuan untuk menguji apakah dalam model regresi, variabel pengganggu atau residual memiliki distribusi normal. Dalam penelitian ini pengujian normalitas dilakukan uji statistik kolmogorovsmirnov.

Tabel 1. Hasil Uji-Normalitas

\begin{tabular}{lrr}
\hline & & Unstandardiz ed Residual \\
\hline $\mathrm{N}$ & & 50 \\
Normal parameters $\mathrm{a}, \mathrm{b}$ & Mean & .0000000 \\
& Std Deviation & .57861834 \\
Most Extreme & Absolute & .074 \\
Differences & Positive & .074 \\
& Negative & -.064 \\
Test Statistic & & .074 \\
Asymp. Sig. (2-tailed) & $.200^{c, d}$ \\
\end{tabular}

Sumber: Data Primer Diolah tahun 2021 
Dari hasil uji kolmogorov-smirnov di atas, dihasilkan nilai Asymp. Sig. (2-tailed) lebih dari 0,05. Hasil uji normalitas menunjukkan bahwa variabel yang diamati berdistribusi normal karena nilai Asymp.sig (2-tailed) sebesar 0,200 yang artinya lebih besar dari signifikan 0,05. Hal tersebut dapat disimpulkan bahwa data residual dalam model regresi ini terdistribusi normal model regresi tersebut layak digunakan untuk analisis selanjutnya.

\section{Uji Multikolinieritas}

Dari hasil perhitungan pada Tabel 5.2 diperoleh bahwa pada bagian collinierity statistic, nilai VIF pada seluruh variabel independen lebih kecil dari 10 dan nilai tolerance di atas 0,1 . Hasil tersebut dapat diartikan bahwa seluruh variabel independen pada penelitian ini tidak ada gejala multikolinieritas. Artinya antara variabel bebas terjadi hubungan linieritas yang sempurna.

Tabel 2. Uji Multikolinieritas

\begin{tabular}{lcc}
\hline \multicolumn{1}{c}{ Variabel } & Tolerance & VIF \\
\hline Ln_Pendapatan RT $\left(\mathrm{X}_{1}\right)$ & .848 & 1.179 \\
Ln_JumlahAnggota Keluarga $\left(\mathrm{X}_{2}\right)$ & .798 & 1.253 \\
Ln_Umur $\left(\mathrm{X}_{3}\right)$ & .664 & 1.506 \\
Ln_TingkatPendidikan $\left(\mathrm{X}_{4}\right)$ & .624 & 1.602 \\
Ln_Harga Daging Ayam $\left(\mathrm{X}_{5}\right)$ & .886 & 1.129 \\
Ln_Jarak Lokasi $\left(\mathrm{X}_{6}\right)$ & .878 & 1.138 \\
Ln_Harga Daging Sapi $\left(\mathrm{X}_{7}\right)$ & .869 & 1.151 \\
Ln_Harga Ikan Laut $\left(\mathrm{X}_{8}\right)$ & .872 & 1.146 \\
\hline
\end{tabular}

Sumber: Data Primer Diolah Tahun 2021

\section{Uji Heteroskedastisitas}

Dari hasil analisis uji heteroskedastisitas pada Gambar 1 terlihat ttitik-titik menyebar secara acak dan tersebar di atas maupun dibawah angka 0 sumbu Y. Hasil tersebut menunjukkan bahwa tidak terdapat gejala heteroskedastisitas. Artinya tidak ada kesamaan variabel (konstan) dan model regresi dapat dikatakan baik dan ideal.

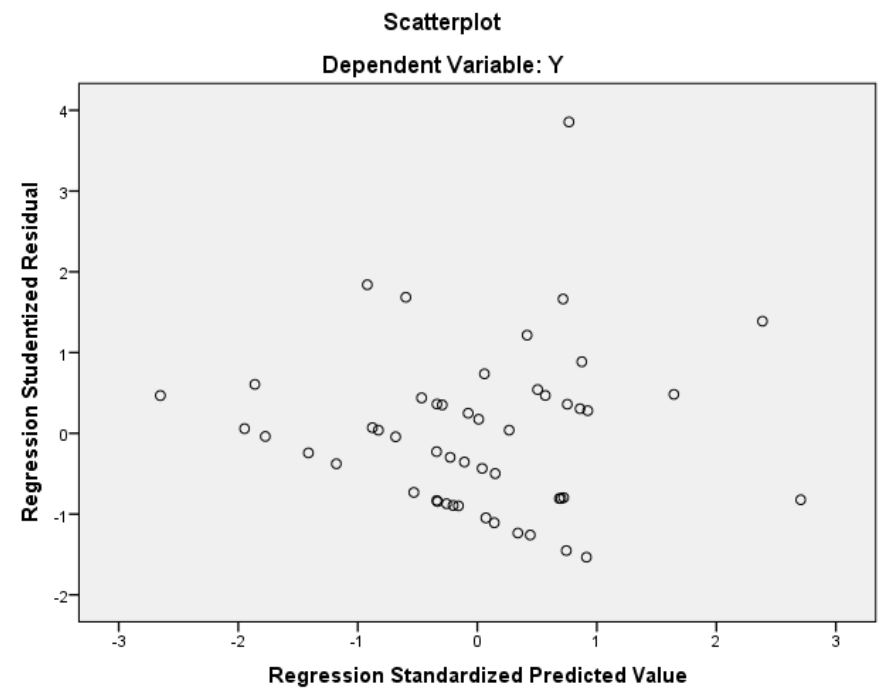

Gambar 1. Scatterplot 


\section{Uji Hipotesa}

\section{Uji Simultan ( Uji F )}

Berdasarkan pengujian hipotesis dengan perhitungan analisis regresi linier berganda menggunakan komputerisasi program SPSS for Windows 22, hasil uji F dilihat pada tabel berikut :

Tabel 3. Uji F

\begin{tabular}{cccc}
\hline Model & F hitung & F tabel & Signifikan \\
\hline Regression & 2.337 & 2,12 & $.048^{\mathrm{b}}$ \\
\hline
\end{tabular}

Sumber: Data Primer Diolah Tahun 2021

Dari uji ANOVA atau $\mathrm{F}$ test di atas, didapat nilai $\mathrm{F}$ hitung sebesar 2.337 dengan tingkat signifikan 0,048 dan nilai $\mathrm{F}$ tabel 2,12. Maka dapat diketahui bahwa Nilai F Hitung $>\mathrm{F}$ Tabel $(2,337>2,12)$. Menunjukkan bahwa semua variabel bebas (X) terdiri dari pendapatan rumah tangga, jumlah anggota keluarga, umur, tingkat pendidikan formal, harga daging ayam broiler, jarak lokasi pembelian, harga daging sapi dan harga ikan laut secara bersama-sama berpengaruh nyata terhadap variabel terikat (Y). Hal ini dikarenakan daging ayam ras broiler pada saat ini menjadi lauk wajib bagi masyarakat sebagai sumber protein dibandingkan daging hewani lain yang mengandung protein masyarakat lebih memilih daging ayam ras broiler.

\section{Uji Parsial (Uji t)}

Uji parsial atau uji t adalah pengujian yang dilakukan untuk mengetahui pengaruh dari setiap variabel independen terhadap variabel dependen. Pengujian hipotesis secara parsial ini dimaksudkan untuk menguji faktor yang mempengaruhi permintaan konsumen daging ayam ras broiler $(\mathrm{Y})$ dan seberapa besar pengaruh dari masing-masing variabel bebas yaitu pendapatan rumah tangga $\left(X_{1}\right)$, jumlah anggota keluarga $\left(X_{2}\right)$, umur $\left(X_{3}\right)$, tingkat pendidikan $\left(\mathrm{X}_{4}\right)$, harga daging ayam ras $\operatorname{broiler}\left(\mathrm{X}_{5}\right)$, jarak lokasi pembelian $\left(\mathrm{X}_{6}\right)$, harga daging sapi $\left(\mathrm{X}_{7}\right)$ dan harga ikan laut $\left(\mathrm{X}_{8}\right)$.

Tabel 4. Uji t

\begin{tabular}{lcrr}
\hline \multicolumn{1}{c}{ Variabel } & t Hitung & t Tabel & Signifikan \\
\hline Pendapatan Rumah Tangga $\left(\mathrm{X}_{1}\right)$ & 1.650 & 1.681 & .107 \\
Jumlah Anggota Keluarga $\left(\mathrm{X}_{2}\right)$ & -.948 & 1.681 & .349 \\
Umur $\left(\mathrm{X}_{3}\right)$ & -1.019 & 1.681 & .314 \\
Tingkat Pendidikan Formal $\left(\mathrm{X}_{4}\right)$ & -2.609 & 1.681 & .013 \\
Harga Daging Ayam Broiler $\left(\mathrm{X}_{5}\right)$ & -1.181 & 1.681 & .245 \\
Jarak Lokasi Pembelian $\left(\mathrm{X}_{6}\right)$ & -.901 & 1.681 & .373 \\
Harga Daging sapi $\left(\mathrm{X}_{7}\right)$ & -.072 & 1.681 & .943 \\
Harga Ikan Laut $\left(\mathrm{X}_{8}\right)$ & .092 & 1.681 & .927
\end{tabular}

Sumber: Data Primer Diolah Tahun 2021

\section{1.) Pendapatan Rumah Tangga $\left(X_{1}\right)$}

Pengaruh Pendapatan Rumah Tangga terhadap permintaan konsumen daging ayam ras broilerberdasarkan hasil perhitungan dalam Tabel 5.5 menunjukkan bahwa, untuk variabel pendapatan rumah tangga diperoleh t hitung sebesar 1,650 (nilai t hitung< $\mathrm{t}$ tabel $=1,650<1,681$ ) pada taraf kepercayaan 0,05 maka H0 diterima dan Hi ditolak. Dengan nilai signifikan 0,107, makahal ini menunjukkan bahwa variabel pendapatan 
rumah tangga $\left(\mathrm{X}_{1}\right)$ tidak berpengaruh secara nyata terhadap permintaan daging ayam ras broiler (Y). Dengan nilai koefisien regresi sebesar 0,259. Artinya jika pendapatan rumah tangga naik $10 \%$ maka permintaan daging ayam broiler menurun2,5\%.

Menurut Mandala dan Prathama (2008), menyatakan bahwa tingkat pendapatan rumah tangga per kapita dapat mencerminkan daya beli. Makin tinggi tingkat pendapatan daya beli makin kuat, sehingga permintaan terhadap suatu barang meningkat. Dalam kasus ini berdasarkan data yang diperoleh di lapangan pendapatan tidak berpengaruh terhadap permintaan daging ayam broiler. Namun dalam kasus ini berdasarkan hasil penelitian, pendapatan konsumen tidak berpengaruh terhadap tingkat permintaan konsumen karena tinggi rendahnya pendapatan konsumen tidak menentukan permintaan meningkat, sebab bukan tingginya pendapatan yang menentukan permintaan terhadap daging ayam ras broilernamun kesadaran atau keinginan dalam setiap konsumen.

Hal ini tidak sesuai dengan penelitian Rahmawati (2009) yang menyebutkan bahwa pendapatan berpengaruh nyata terhadap permintaan daging ayam ras broiler. Dengan nilai koefisien regresi sebesar 0,017327. Artinya jika pendapatan naik sebesar $10 \%$ maka permintaan daging ayam ras broiler akan naik sebesar $0,17 \%$.

\section{2.) Jumlah Anggota Keluarga $\left(X_{2}\right)$}

Pengaruh jumlah anggota keluarga terhadap permintaan daging ayam ras broiler berdasarkan hasil perhitungan dalam Tabel 5.5 menunjukan bahwa, untuk variabel jumlah anggota keluarga diperoleh $t$ hitung sebesar $-0,948$ ( nilai $t$ hitung $<\mathrm{t}$ tabel $=-0,948<1,681$ ) maka H0 diterima Hi ditolak. Dengan nilai signifikan 0,349, maka hal ini menunjukkan bahwa variabel jumlah anggota keluarga $\left(\mathrm{X}_{2}\right)$ tidak berpengaruh secara nyata terhadap permintaan daging ayam ras broiler (Y).Dengan nilai koefisien regresi sebesar -0,321. Artinya jika jumlah anggota keluarga bertambah 1 orang maka permintaan daging ayam ras broiler berkurang 0,321 kg. Hal ini tidak sejalan dengan penelitian Pranata (2013) yang menyatakan bahwa permintaan daging ayam di kota Medan dipengaruhi secara nyata oleh jumlah anggota keluarga. Semakin banyak jumlah anggota keluarga maka akan meningkat jumlah permintaan daging ayam broiler. Dengan diperoleh koefisien regresi 0,129 yang artinya setiap bertambahnya 1 anggota keluarga maka permintaan akan meningkat sebesar 0,129 kg. Peningkatan angggota keluarga juga berbanding lurus dengan peningkatan jumlah masyarakat. Sehingga jika anggota keluarga bertambah maka jumlah permintaan daging ayam ras juga akan meningkat.

\section{3.) Umur ( $\left.X_{3}\right)$}

Pengaruh umur terhadap permintaan daging ayam ras broiler berdasarkan hasil perhitungan yang terangkum dalam Tabel 5.5 di atas, menunjukkan bahwa, untuk variabel umur diperoleh $\mathrm{t}$ hitung sebesar $-1,019$ ( nilai $\mathrm{t}$ hitung $<\mathrm{t}$ tabel $=-1,019<1,681$ ) maka H0 diterima Hi ditolak. Dengan nilai signifikan 0,314, maka hal ini menunjukkan bahwa variabel umur $\left(\mathrm{X}_{3}\right)$ tidak berpengaruh secara nyata terhadap permintaan daging ayam ras broiler (Y). Diperoleh nilai koefisien regresi sebesar -0,401. Artinya jika umur bertambah 1 tahun maka permintaan terhadap daging ayam ras menurun sebesar 0,401 kg. Sesuai dengan hasil penelitian di lapangan tidak ada batasan umur untuk menjadi konsumen daging ayam ras broiler dari balita hingga usia lanjut konsumen tetap mengkonsumsi daging ayam ras broiler. Hal ini tidak sejalan dengan penelitian Hajiis (2018) yang menyatakan bahwa umur mempengaruhi secara nyata terhadap permintaan daging ayam ras broiler di kota Pematangsiantar. Diperoleh hasil koefisien regresi umur ialah 0,008 yang artinya jika usia bertambah 1 tahun maka jumlah permintaan akan bertambah sebesar 0,008 kg. 


\section{4.) Tingkat Pendidikan $\left(X_{4}\right)$}

Pengaruh tingkat pendidikan terhadap permintaan daging ayam ras broiler berdasarkan hasil perhitungan Tabel 5.5 menunjukkan bahwa, untuk variabel tingkat pendidikan diperoleh $t$ hitung sebesar $-2,609$ ( nilai $t$ hitung $>t$ tabel $=-2,609>1,681$ ) maka H0 ditolak dan Hi diterima. Dengan nilai signifikan 0,013, makahal ini menunjukkan bahwa variabel umur $\left(\mathrm{X}_{4}\right)$ berpengaruh terhadap permintaan daging ayam ras broiler (Y). Sesuai hasil penelitian di pasar Panarukan sebagian besar konsumen daging ayam ras broiler memiliki pendidikan tinggi. Karena daging ayam ras broiler merupakan bahan pokok yang saat ini sangat diminati oleh semua kalangan sebagi sumber protein hewani. Responden yang berpendidikan minimal SMA memiliki pengetahuan dalam memenuhi protein yang dibutuhkan oleh tubuh untuk meningkatkan sistem imun pada masa pandemi Covid-19.

Hal ini tidak sejalan dengan hasil penelitian Pranata (2013) yang menyatakan permintaan daging ayam ras broiler di kota Medan tidak dipengaruhi secara nyata oleh tingkat pendidikan. Hal ini disebabkan karena daging ayam broiler merupakan jenis bahan makanan yang tergolong umum di masyarakat, sehingga setiap masyarakat sudah biasa mengkonsumsi daging ayam broiler. Koefisien regresi yang diperoleh sebesar -0,009062. Artinya bahwa jika pendidikan naik 1 tingkat maka permintaan daging ayam ras broiler turun sebesar 0,009062 kg, begitu pula sebaliknya.

\section{5.) Harga Daging Ayam Ras Broiler $\left(\mathrm{X}_{5}\right)$}

Pengaruh Harga Daging Ayam Ras Broiler terhadap permintaan daging ayam ras broiler berdasarkan hasil perhitungan dalam Tabel 5.5 menunjukkan bahwa, untuk variabel Harga Daging Ayam Ras Broiler diperoleh t hitung sebesar -1,181( nilai t hitung< $\mathrm{t}$ tabel $=-1,181<1,681$ ) maka $\mathrm{H0}$ diterima dan Hi ditolak. Dengan nilai signifikan 0,245,maka hal ini menunjukkan bahwa harga daging ayam ras broiler $\left(\mathrm{X}_{5}\right)$ tidak mempengaruhi secara nyata terhadap permintaan (Y). Diperoleh nilai koefisien -8,131. Artinya setiap terjadi kenaikan harga Rp.1.000, maka tingkat permintaan terhadap daging ayam ras menurun sebesar $8.131 \mathrm{~kg}$. Sesuai penelitian di Pasar Panarukan tingginya harga daging ayam ras broiler tidak mengurangi permintaan terhadap daging ayam ras broiler.

Hal ini sejalan dengan Penelitian Hajiis (2018) menyatakan bahwa harga daging ayam ras di kota Pemantangsiantar tidak mempengaruhi secara nyata terhadap permintaan daging ayam ras broiler. Hasil koefisien regresi harga daging ayam ras ialah 0,000004158 artinya setiap kenaikan harga Rp.1 maka tingkat permintaan berkurang sebesar 0,000004158 .

\section{6.) Jarak Lokasi Pembelian $\left(\mathrm{X}_{6}\right)$}

Jarak lokasi pembelian daging ayam ras broiler berdasarkan hasil perhitungan yang terangkum di Tabel 5.5 di atas, mennjukkan bahwa variabel jarak di peroleh t hitung $-0,901$ (nilai $t$ hitung $<\mathrm{t}$ tabel $=-0,901<1,681$ ) maka H0 diterima dan Hi ditolak. Dengan nilai signifikan 0,373 . Hal ini menunjukkan bahwa variabel jarak lokasi pembelian $\left(\mathrm{X}_{6}\right)$ tidak mempengaruhi tingkat permintaan (Y). Diperoleh nilai koefisien regresi -0,087. Artinya jika jarak lokasi bertambah jauh $1 \mathrm{~km}$, maka permintaan daging ayam ras broiler berkurang $87 \mathrm{~kg}$. Dari hasil penelitian yang menjadi reponden penelitian ini memiliki jarak lokasi pembelian yang dekat dengan pasar atau masyarakat Kecamatan panarukan dan Kecamatan Kendit.

\section{7.) Harga Daging Sapi}

Harga daging sapi berdasarkan hasil perhitungan yang terangkum di Tabel 5.5 di atas, menyatakan bahwa variabel harga daging sapi diperoleh $t$ hitumg $-0,072$ ( nilai $t$ hitung $<\mathrm{t}$ tabel $=0,072<1,681$ ) maka H0 diteima dan Hi ditolak. Dengan nilai signifikan 
0,943. Hal ini menunjukkan bahwa variabel harga daging sapi $\left(\mathrm{X}_{7}\right)$ tidak mempengaruhi tingkat permintaan (Y). Diperoleh nilai koefisien regresi -0,175. Artinya jika harga daging sapi naik sebesar $10 \%$ maka pemintaan daging ayam ras broiler menurun sebesar $1,7 \%$. Sesuai penelitian di lapangan menyatakan bahwa harga daging sapi tidak mempengaruhi permintaan terhadap daging ayam ras broiler karena daging sapi merupakan barang pelengkap atau komplementer.

\section{8.) Harga Ikan Laut}

Harga ikan laut berdasarkan hasil perhitungan yang terangkum di Tabel $5.5 \mathrm{di}$ atas, menyatakan bahwa variabel harga ikan laut diperoleh t hitung 0,092 (nilai t hitung < t tabel $=0,092<1,681$ ) maka H0 diterima dan Hi ditolak. Dengan nilai signifikan 0,927. Hal ini menunjukkan bahwa variabel harga ikan laut $\left(\mathrm{X}_{8}\right)$ tidak mempengaruhi tingkat permintaan (Y). Diperoleh nilai koefisien regresi 0,199. Artinya jika harga ikan laut meningkat sebesar $10 \%$ maka akan meningkatkan permintaan daging ayam ras broiler sebesar 1,9\%. Hal ini disebabkan karena harga ikan laut dengan harga daging ayam ras broiler tidak terlalu jauh berbeda, sesuai hasil penelitian dilapangan menyatakan bahwa ikan laut merupakan barang subsitusi atau pengganti daging ayam ras broiler jika harga ikan laut meningkat konsumen akan membeli ikan laut sebagai sumber protein untuk tetap menjaga kekebalan sistem imun.

\section{Koefisien Determinasi}

Tabel 5. Hasil Perhitungan Koefisien Determinasi

\begin{tabular}{lll}
\hline $\mathrm{R}$ & $\mathrm{R}$ Square & Adjusted R Square \\
\hline $.496^{\mathrm{a}}$ & .246 & .099 \\
\hline
\end{tabular}

Sumber: Data Primer Diolah Tahun 2021

Dari data tampilan output SPSS model summary di atas, besarnya $\mathrm{R}^{2}$ adalah 0,246 atau $24,6 \%$ berpengaruh kecil terhadap permintaan konsumen daging ayam ras Broilerdapat dijelaskan oleh variabel pendapatan rumah tangga, jumlah anggota keluarga, umur, pendidikan, harga daging ayam ras broiler, jarak, harga daging sapi dan harga ikan laut. Sedangkan sisanya 75,4\% dipengaruhi oleh variabel lain di luar model. Variabel lain tersebut seperti selera dan olahan masakan berbahan daging ayam ras yang siap saji, karena pada jaman modern saat ini banyak sekali inovasi baru yang memberikan sajian berbahan daging ayam ras broiler yang sangat diminati setiap kalangan masyarakat. Misalnya sosis ayam, nuget ayam, bakso ayam dan masih banyak olahan lain berbahan daging ayam.

\section{KESIMPULAN}

Dari hasil penelitian yang telah dilakukan, maka didapat kesimpulan yaitu Pendapatan rumah tangga $\left(X_{1}\right)$, jumlah anggota keluarga $\left(X_{2}\right)$, umur $(X)$, tingkat pendidikan $\left(\mathrm{X}_{4}\right)$, harga daging ayam ras broiler $\left(\mathrm{X}_{5}\right)$, jarak lokasi pembelian $\left(\mathrm{X}_{6}\right)$, harga daging sapi $\left(\mathrm{X}_{7}\right)$, dan harga ikan laut $\left(\mathrm{X}_{8}\right)$ secara simultan berpengaruh terhadap permintaan daging ayam ras broiler di pasar Panarukan Kecamatan Panarukan (Y) dengan tingkat signifikan 0,048. Tingkat pendidikan secara parsial berpengaruh nyata terhadap permintaan daging ayam ras broiler di pasar Panarukan. Sedangkan variabel pendapatan rumah tangga, jumlah anggota keluarga, umur, tingkat pendidikan, harga daging ayam ras broiler, jarak lokasi pembelian, harga daging sapi dan harga ikan laut secara parsial tidak berpengaruh nyata terhadap permintaan daging ayam ras broiler di pasar Panarukan. 


\section{DAFTAR PUSTAKA}

Abubakar. 2009. Teknologi Pemotongan Ayam Halal dan Penerapannya di RAP Tradisional.http://food-scientistresearch.blogspot.com/2009/03/Teknologi Pemotongan-ayam-halal-dan. Html (22 Mei 2016).

Hajiis, R. 2018. Analisis Faktor-faktor yang Mempengaruhi Permintaan Daging Ayam Broiler di Kota Pematangsiantar.

Indrawati, S Mulyani. 2020. Tantangan Akuntabilitas Keuangan Negara Dalam Penanganan Pandemi Covid-19 Dan Pemulihan Ekonomi Nasional. Rekarnas Akuntansi Dan Pelapor Keuangan Pemerintah 2020, Jakarta, $22 \quad$ September /2020.

Pranata, E. 2013. Analisis Permintaan Ayam Broiler/Pedaging. Skripsi Jurusan Agribisnis Fakultas Pertanian Universitas Sumatera Utara Medan.

Rahmawati, D. 2009. Faktor-faktor yang Mempengaruhi Permintaan Daging Ayam di Jawa Tengah Tahun 1986-2006.Skripsi. Jurusan Ekonomi Pembangunan, Fakultas Ekonomi, Universitas Sebelas Maret. Digital Library Universitas Sebelas Maret. Purwokerto.

WHO. (2020). Menu Gizi Seimbang. 